\title{
Effect of Institutional Ownership on Dividends: An Agency-theory-based Analysis
}

\begin{abstract}
This study examines the effect of institutional ownership on dividend payouts through the lens of agency theory. We hypothesize that only institutions with certain traits are likely to monitor. Monitoring institutions will use dividend payouts as a tool to mitigate firms' agency problems, conditional on those firms' financial performance. We find that (1) there is a positive relation between lagged long-term institutional ownership with a large stake and the dividend payout ratio; (2) the positive relation is more salient in firms with high agency costs; and (3) the positive relation is more salient when external monitoring is weak. These findings support that (1) concentrated and long-term institutional investors play a monitoring role and (2) monitoring institutions use dividend payouts as a monitoring device. Our findings are robust to endogeneity tests, level and change models, alternative income-based dividend payout measures, alternative measures of long-term institutions, and sub-period analyses.
\end{abstract}

Keyword: institutional investor, agency theory, monitoring, long-term, dividends JEL classification: G23, G32, G35

Highlights

- Long-term institutional investors with large stakes (Top10LTIO) monitor.

- Top10LTIO use dividend payouts as a monitoring device.

- Higher dividend payouts with higher Top10LTIO where agency costs are high.

- Higher dividend payouts with higher Top10LTIO where external monitor system is weak. 


\section{Effect of Institutional Ownership on Dividends: An Agency-theory-based Analysis}

\section{Introduction}

This paper investigates the influence of monitoring institutional investors on firms' dividend payouts and explores whether this influence is related to agency costs. Whereas both institutional investors and dividends are documented to mitigate agency costs (Chen, Harford, and Li, 2007; John, Knyazeva and Knyazeva, 2011), our study focuses on whether and how institutional investors use dividend payouts as a tool to accomplish the task.

As major shareholders, institutional investors have power over corporate policies, especially when they have concentrated holdings (Hartzell and Starks, 2003) and long-term investment horizons (Gaspar, Massa, and Matos, 2005). Higher dividends can serve as an effective monitoring tool to mitigate the manager-shareholder agency conflict, especially at firms where such agency costs are high (John, Knyazeva and Knyazeva, 2011). We therefore hypothesize that long-term institutions with large ownership stakes use dividend payouts as a monitoring device, especially at firms with high agency costs.

To test our hypotheses, we use the 10 largest long-term institutional shareholders of a firm (Top10LTOwners) as our proxy for institutions that are likely to monitor (monitoring institutions). The Top10LTOwners are likely to be more influential as they have large stakes (Chen, Harford, and $\mathrm{Li}, 2007$ ), more sensitive to agency problems as they have concentrated holdings (Hartzell and Starks, 2003), and have lower monitoring costs due to their long investment horizons (Harford, Kecskes, and Mansi, 2014). We proxy agency costs with positive free cash flow and low Tobin's Q, as firms with these characteristics are likely to be cash cows with poor investment opportunities (Jurkus, Park, and Woodard, 2011). We also proxy agency costs with high earnings management, 
as managers can use earnings management to serve their own interests at the expense of shareholders (Chung, Firth, and Kim, 2005). We use two proxies for information-quality-related external monitoring systems: (1) the Herfindahl-Hirschman index (HHI), which is a product market concentration index, and (2) quality of access to public information. Both proxies are related to external information transparency and influence managers' effort levels (Hart, 1983).

Our empirical findings from a large sample of U.S. firms over the 1995-2009 period provide supporting evidence for our hypotheses. A higher proportion of the Top10LTOwners is associated with a higher future dividend payout ratio. This relation is only salient in firms with high agency costs or weak external monitoring mechanisms. Our findings support the monitoring role of certain institutional investors and are consistent with an agency-theory-based interpretation: the presence of higher proportion of monitoring institutions leads to higher dividend payouts at firms with high agency costs or weak monitoring mechanisms.

Our study also contributes to the literature on the interaction between dividends and other monitoring mechanisms (Allen, Bernardo, and Welch, 2000; Grinstein and Michaely, 2005; Grullon and Michaely, 2012; Officer, 2011; Hoberg, Phillips, and Prabhala, 2014, and others) by providing further empirical evidence supporting the role of dividends as a tool to mitigate agency costs. We confirm the findings of Grinstein and Michaely (2005) that firms with high institutional holdings generally prefer lower dividend payouts. However, unlike Grinstein and Michaely (2005), we show that the Top10LTOwners are likely to monitor and have a different relation with dividend payouts from general institutional owners. When there are other strong external monitoring mechanisms, including product market competition and quality of access to public information, the Top10LTOwners do not influence dividend payouts. Our results are robust to measures of the proportion of shares owned by the Top10LTOwners, endogeneity tests, 
level and change models, sub-period analyses, and a number of dividend payout ratios that are calculated based on alternative measures of the firm's income.

We focus on dividend payments when examining the effect of institutional ownership on firms' payout policies in an agency theory framework. Dividends are stickier than repurchases, and dividend payout is a more credible monitoring device (Farre-Mensa, Michaely, and Schmalz, 2014). Managers state that they will pass up positive net present value projects before cutting dividends, but do not make the same claim about repurchases (Brav, Graham, Harvey, and Michaely, 2005; John and Knyazeva, 2006). However, our results are robust to the inclusion of repurchases. Our results remain largely the same before and after the dividend tax law change in 2003, and after excluding pension funds from our sample. As pension funds face more favorable tax rates compared to other institutions, they are more likely to be subject to the clientele effect. So our findings suggest that a tax-related explanation is less likely.

\section{Development of hypotheses}

Agency theory predicts that manager-shareholder conflicts lead to agency costs, which hurt shareholder value (Jensen, 1986). Previous literature has proposed numerous mechanisms, including both dividends and institutional investors that mitigate agency costs. Through cash disbursement that reduces free cash flow at the firm, dividends can be used as a monitoring device that reduces agency costs, including managers' consumption of perks and overinvestment (Grossman and Hart, 1980; Easterbrook, 1984; Jensen, 1986). Through strengthened corporate governance, institutional investors with certain characteristics serve as monitors and mitigate agency costs. Such monitoring have been reflected by monitoring institutions' influences on executive compensation, earnings management, and mergers and acquisitions (Hartzell and Starks, 2003; Khan, Dharwadkar, and Brandes, 2005; Velury and Jenkins, 2006). 
Institutional investors are only likely to monitor in a cost-efficient setting (Chen, Harford, and Li, 2007). A long investment horizon reduces institutional investors' monitoring costs, making them more likely to monitor (Harford, Kecskes, and Mansi, 2014). As long-term institutional investors are highly desirable to the firm, managers take them seriously (Gaspar, Massa, and Matos, 2005; Beyer, Larcker, and Tayan, 2014). Managers could please their shareholders by pre-committing to dividends. For example, John, Knyazeva, and Knyazeva (2011) show that rural firms have weaker governance mechanisms and pre-commit to higher dividend payouts to mitigate agency conflicts.

At the same time, a large stake increases the probability and effectiveness of monitoring, as institutions can gain access to the board through large holdings (Carleton, Nelson, and Weisbach, 1998). Concentrated long-term institutional investors can therefore vote on dividend policy to address their concerns on manager-shareholder conflicts.

Based on the above arguments, we believe that monitoring institutional investors are likely to be concentrated and long-term and propose the following joint hypothesis: Hypothesis 1: Top 10LTOwners are likely to monitor and a higher proportion of Top10LTOwners is associated with greater future dividend payouts.

Our Hypothesis 1 is closely related to the findings in Crane, Michenaud, and Weston (2014) with an important distinction. Whereas Crane, Michenaud, and Weston (2014) suggest that higher overall institutional ownership causes firms to pay more dividends and repurchase more shares, we argue that only concentrated long-term institutional ownership is positively associated with dividend payouts.

Following an agency-theory-based interpretation of dividends, ceteris paribus, monitoring institutions are more likely to intervene in firms with high agency costs as their benefits from doing so will be higher. Agency costs are likely to be high in firms with both free 
cash flow and poor investment opportunities, as the managers are more likely to have negative net present value projects at these firms (Chung, Firth, and Kim, 2005). As earnings management can also reflect agency costs, the extent of earnings management can serve as a proxy for the presence of an agency cost (Cornett, Marcus, and Tehranian, 2008). If the Top10LTOwners use dividend payouts as a monitoring device, we expect the disciplinary effect to be more salient in firms with high agency costs. We therefore propose the following hypotheses:

Hypothesis 2a: The proportion of Top10LTOwners is positively associated with dividend payouts in firms with both positive free cash flow and poor investment opportunities.

Hypothesis 2b: The proportion of Top10LTOwners is positively associated with dividend payouts in firms with higher earnings management.

Product market competition improves the quality of the information about managerial performance that shareholders can obtain and drives prices toward minimum average costs. Product market competition, therefore, monitors managers to increase firm efficiency (Holmstrom, 1982; Hart, 1983; Nalebuff and Stiglitz, 1983; Giroud and Mueller, 2010). Similar to product market competition, investors' access to public information is another important external monitoring mechanism as managers will be less inclined to discriminate their effort in a more transparent environment. We therefore propose the following hypotheses: Hypothesis 3a: Product market competition influences the relationship between the proportion of Top10LTOwners and dividend payouts.

Hypothesis 3b: The quality of investors' access to public information influences the relation between the proportion of Top10LTOwners and dividend payouts.

\section{Data and main results}

\subsection{Data}

We use Thomson Reuters' 13F quarterly institutional common stock holdings data for the institutional ownership variables and the Compustat and Center for Research in Security Prices 
(CRSP) databases for the financial data. The $13 \mathrm{~F}$ mandatory institutional reports are filed with the Securities and Exchange Commission (SEC) on a calendar quarter basis and are compiled by Thomson Reuters (formerly known as the 13F CDS/Spectrum database). The SEC's Form 13F requires all institutions with more than $\$ 100$ million under management at the end of the year to report their long positions of equity. The reported positions are those in which the institution owns more than 10,000 shares or shares of over $\$ 200,000$ in market value. Our sample includes all publicly traded U.S. firms in the CRSP and Compustat databases between 1995 and 2009 that have CRSP share codes of 10 or 11 . We exclude firms that are financials or utilities and firms with zero institutional ownership. For each firm that has non-missing and non-zero institutional ownership, we calculate the ratio of shares owned by the 10 largest shareholders to the total shares outstanding as our measure of ownership concentration (Top10own), similar to Burns, Kedia, and Lipson (2010). We differentiate institutional investors as long-term or short-term based on Bushee's categorization that is available at Professor Bushee's personal site: (http://acct3.wharton.upenn.edu/faculty/bushee/). According to Bushee (1998), dedicated institutional investors are characterized by large average investments in portfolio firms with extremely low turnover ratios, quasi-indexers are characterized by low turnover and diversified holdings, and transient investors have high portfolio turnover ratios and highly diversified portfolio holdings. We categorize both dedicated and quasi-index institutional ownership as long-term and transient ownership as short-term. We calculate the ratio of shares owned by institutions that are the10 largest shareholders (Top10Own). Out of Top10Own, we define the ratio of shares owned by these top10 owners with a long-term investment horizon as Top10LTIO and that by top10 owners with a short-term investment horizon as Top 10STIO, respectively. We define the dividend payout ratio as cash dividends normalized by net income. 
Institutional investors may condition their use of dividend payouts as a monitoring device on the economic condition of the firm. A firm can have a negative net income for various reasons, such as poor performance, major investments, and a large one-time write off. We conjecture that the Top10LTOwners are more likely to use dividend payouts as a monitoring device when the firm has a positive net income. To investigate how monitoring institutional ownership influences dividend payouts to alleviate agency costs, we limit our sample to firms with positive earnings in the previous year. After imposing the above restrictions, our sample contains 31,140 firm-year observations from 5,977 unique firms over 1995-2009.

We control for differences between firms using the logarithm of the firm's market capitalization (to control for the size effect), firm age (to control for the lifecycle effect documented by DeAngelo, DeAngelo, and Stulz, 2006), past volatility of the firm's stock, leverage, cash ratio, return on assets, sales growth (a proxy for investment opportunities), and proportion of fixed assets. Past volatility is calculated based on monthly stock returns over the past two years and controls for firm risk. We winsorize all of the ownership and control variables at the $1 \%$ and $99 \%$ levels to alleviate the effect of outliers.

\subsection{Summary statistics}

Table 1 presents the summary statistics for all of the variables. Our main dependent variable, the dividend payout ratio, is the cash dividend divided by the net income during the previous year. The mean dividend payout ratio is $21.1 \%$, with a median of 0 and a standard deviation of $47.0 \%$. The $75 \%$ percentile is $25.4 \%$. We also calculate the average dividend payout ratio for the firms without a restriction on positive net income and find that the mean, median, and standard deviation of the dividend payout ratio are $12.6 \%, 0$, and $42.6 \%$, respectively. The other dividend payout measures — cash dividends normalized by income before extraordinary items $(I B)$, earnings before interest and taxes $(E B I T)$, contemporaneous net income $(N I)$, market 
value, and total payouts normalized by net income —are also higher for our sample of firms. Our sample also has higher profitability (mean ROA at $1.9 \%$ vs $-4.5 \%$ ) and a lower cash holding ratio and sales growth rate than the firms without a positive net income restriction.

Table 1. Descriptive statistics

Table 1 reports the descriptive statistics for main variables used in our study over the period of 1995 2009.

\begin{tabular}{|c|c|c|c|c|c|c|}
\hline Variable & $\mathrm{N}$ & Mean & Median & P25 & P75 & SD \\
\hline $\mathrm{Div}_{\sqrt{ }} / N I_{t-1}$ & 31140 & 0.211 & 0.000 & 0.000 & 0.254 & 0.470 \\
\hline Div Dum $_{t}$ & 31043 & 0.411 & 0.000 & 0.000 & 1.000 & 0.492 \\
\hline $\mathrm{Div}_{t} / I B_{t-1}$ & 31140 & 0.210 & 0.000 & 0.000 & 0.254 & 0.485 \\
\hline$D i v_{t} / E B I T_{t-1}$ & 31131 & 0.110 & 0.000 & 0.000 & 0.145 & 0.236 \\
\hline $\operatorname{Div}_{t} / N I_{t}$ & 31139 & 0.161 & 0.000 & 0.000 & 0.203 & 0.483 \\
\hline Div Yield $t_{t}$ & 31039 & 0.009 & 0.000 & 0.000 & 0.014 & 0.017 \\
\hline $\operatorname{Div}_{/}$Mktcap $_{t-1}$ & 30977 & 0.010 & 0.000 & 0.000 & 0.015 & 0.018 \\
\hline$D v c_{t} / N I_{t}$ & 31043 & 0.150 & 0.000 & 0.000 & 0.195 & 0.384 \\
\hline Totpay $_{t} / N_{t}$ & 29185 & 0.453 & 0.134 & 0.000 & 0.631 & 1.126 \\
\hline $\log (M V)$ & 31081 & 6.160 & 6.144 & 4.652 & 7.541 & 2.106 \\
\hline Leverage & 31031 & 0.205 & 0.179 & 0.021 & 0.326 & 0.189 \\
\hline Cash/TA & 31135 & 0.156 & 0.081 & 0.024 & 0.228 & 0.181 \\
\hline$R O A$ & 31140 & 0.046 & 0.054 & 0.020 & 0.092 & 0.110 \\
\hline Sale's Growth & 31081 & 0.141 & 0.092 & -0.003 & 0.221 & 0.319 \\
\hline Tobin's $Q$ & 29643 & 1.930 & 1.482 & 1.101 & 2.192 & 1.469 \\
\hline Net FA/TA & 31082 & 0.288 & 0.221 & 0.106 & 0.416 & 0.231 \\
\hline Log(Firm age) & 31128 & 2.516 & 2.546 & 1.873 & 3.219 & 0.869 \\
\hline Past volatility & 26628 & 0.136 & 0.121 & 0.088 & 0.167 & 0.070 \\
\hline$F C F / T A$ & 27250 & 0.099 & 0.099 & 0.062 & 0.142 & 0.089 \\
\hline Total IOR & 31140 & 0.521 & 0.550 & 0.267 & 0.771 & 0.297 \\
\hline Top10own & 31140 & 0.342 & 0.346 & 0.214 & 0.458 & 0.185 \\
\hline Top10LTIO & 31140 & 0.253 & 0.239 & 0.126 & 0.359 & 0.165 \\
\hline Top10STIO & 31140 & 0.075 & 0.048 & 0.010 & 0.111 & 0.083 \\
\hline ZIP2 Top10LTIO & 31104 & 0.540 & 0.533 & 0.467 & 0.605 & 0.134 \\
\hline FF48 Top10LTIO & 31139 & 0.543 & 0.542 & 0.482 & 0.602 & 0.087 \\
\hline$H H I$ & 31139 & 0.080 & 0.056 & 0.032 & 0.091 & 0.086 \\
\hline
\end{tabular}




\subsection{Institutional ownership and dividend payouts}

We first examine how institutional ownership in the previous year influences the firm's propensity to pay dividends. The results are reported in Columns (1)-(3) in Table 2. The dependent variable is a dividend dummy that equals 1 if the firm pays dividends and 0 otherwise. The results from the logit models show that the total ownership by institutions (Total IOR), ownership by institutions with largest stakes in the firm (Top10own), and ownership by these institutions that have both large stakes and short-term investment horizons (Top10STIO) are all negatively associated with future propensity to pay dividends. There is also no significant relation between Top10LTIO and the dividend-paying propensity. The propensity to pay dividends increases with an increase in firm size, fixed assets ratio, firm age, or profitability, and decreases with an increase in leverage, cash ratio, sales growth, or firm risk.

When analyzing the effect of institutional ownership on dividend payouts, omitted unobservable firm characteristics may lead to spurious results due to endogeneity concerns. For example, some firms may have founding CEOs who are reluctant to pay dividends and this attitude may then become a part of the corporate culture. We can address the concern that omitted time-invariant firm characteristics drive our results by controlling for firm fixed effects in the regression models. The Chi-square statistic from the Hausman test is highly significant, suggesting a panel firm fixed effect model is preferred to a panel random effects model.

We then use firm fixed effects models to investigate how different types of institutional ownership in the previous year influence the dividend payout ratio. The dividend payout ratio increases with an increase in firm size or cash ratio, and decreases with an increase in leverage, firm risk, or profitability. This suggests that different firm characteristics influence both the propensity to pay dividends and the dividend payout ratio. The results reported in Columns (4)(6) of Table 2 show that greater Total IOR is not significantly associated with the dividend 
payout ratio. Top10own and Top10LTIO are both positively associated with the dividend payout ratio, supporting Hypothesis 1. Top10STIO is not associated with the dividend payout ratio. Our findings show that different types of institutional ownership have different effects on the propensity to pay and the magnitude of the payout ratio. This suggests that ownership types affect how institutional investors use dividends as a channel for monitoring.

As Top10LTIO and Top10STIO add up to Top10IO, a regression including Top10IO with Top1OLTIO and Top1OLSTO is subject to problems caused by severe multicolinearity. We therefore focus on results from regressions using the following three ownership variables: Total IOR, Top 1OLTIO, and Top10STIO and report results in Column (7) of Table 2. Whereas Total IOR describes the effect of overall institutional ownership, Top10LTIO and Top10STIO capture the incremental effect of ownership concentration and investment horizons. The effect of the Top10LTOwners on dividend payouts is therefore calculated as the sum of effects from Total IOR and Top10LTIO $(0.240-0.138=0.102$ in Column (7)). To test the null joint hypothesis that there is no effect of the Top10LTOwners on dividend payout, we conduct a partial $F$-test on the parameters of Total IOR and Top10LTIO (Kennedy, 1996, p.89). The partial F-statistic is 7.14 and significant at the $1 \%$ level. Even though not tabulated, when we add control of industry-year fixed effects, our results continue to hold. 
[Table 2 on Page 24]

Table 2. Propensity to pay and dividend payout regressions

Table 2 reports the relation between lagged institutional ownership of various types and dividend payout. Columns (1) - (3) report results from logit regressions with the dependent variable being Div Dum. Columns (4) - (7) report results from panel firm fixed effects regressions with the dependent variable being $\operatorname{Div}_{t} / N I_{t-1}$. All model standard errors are robust standard errors clustered at the firm level.

\begin{tabular}{|c|c|c|c|c|c|c|c|}
\hline VARIABLES & $\begin{array}{c}\text { (1) } \\
\text { Div Dum }\end{array}$ & $\begin{array}{c}(2) \\
\text { Div Dum }\end{array}$ & $\begin{array}{c}\text { (3) } \\
\text { Div Dum }\end{array}$ & $\begin{array}{c}(4) \\
D i v_{t} / N I_{t-1}\end{array}$ & $\begin{array}{c}(5) \\
\text { Divt/NIt-1 }\end{array}$ & $\begin{array}{c}(6) \\
\text { Divt/NIt-I }\end{array}$ & $\begin{array}{c}(7) \\
\text { Divt/NIt-I }\end{array}$ \\
\hline $\log (M V)_{t-1}$ & $\begin{array}{c}0.397 * * * \\
(12.646)\end{array}$ & $\begin{array}{c}0.323 * * * \\
(12.595)\end{array}$ & $\begin{array}{c}0.320 * * * \\
(12.364)\end{array}$ & $\begin{array}{l}0.012^{*} \\
(1.894)\end{array}$ & $\begin{array}{c}0.009 \\
(1.588)\end{array}$ & $\begin{array}{l}0.011^{*} \\
(1.831)\end{array}$ & $\begin{array}{c}0.020^{* * * *} \\
(2.946)\end{array}$ \\
\hline Leveraget-1 & $\begin{array}{c}-0.904 * * * \\
(-3.841)\end{array}$ & $\begin{array}{c}-0.921^{* * * *} \\
(-3.894)\end{array}$ & $\begin{array}{c}-0.919 * * * \\
(-3.899)\end{array}$ & $\begin{array}{c}-0.117 * * * \\
(-3.397)\end{array}$ & $\begin{array}{c}-0.117^{* * *} \\
(-3.409)\end{array}$ & $\begin{array}{c}-0.117 * * * \\
(-3.394)\end{array}$ & $\begin{array}{c}-0.115 * * * \\
(-3.336)\end{array}$ \\
\hline Cash/TA t-1 & $\begin{array}{c}-1.085^{* * *} \\
(-3.624)\end{array}$ & $\begin{array}{c}-1.066 * * * \\
(-3.576)\end{array}$ & $\begin{array}{c}-1.040 * * * \\
(-3.479)\end{array}$ & $\begin{array}{c}0.151 * * * \\
(4.227)\end{array}$ & $\begin{array}{c}0.146^{* * *} \\
(4.106)\end{array}$ & $\begin{array}{c}0.151^{* * * *} \\
(4.220)\end{array}$ & $\begin{array}{c}0.156^{* * *} \\
(4.390)\end{array}$ \\
\hline$R O A_{t-1}$ & $\begin{array}{c}3.151^{* * * *} \\
(4.803)\end{array}$ & $\begin{array}{c}3.214 * * * \\
(4.855)\end{array}$ & $\begin{array}{c}3.341 * * * \\
(5.047)\end{array}$ & $\begin{array}{c}-1.685 * * * \\
(-14.895)\end{array}$ & $\begin{array}{c}-1.667 * * * \\
(-14.787)\end{array}$ & $\begin{array}{c}-1.662 * * * \\
(-14.757)\end{array}$ & $\begin{array}{c}-1.663 * * * \\
(-14.758)\end{array}$ \\
\hline Sale's Growth ${ }_{t-1}$ & $\begin{array}{c}-1.097 * * * \\
(-9.984)\end{array}$ & $\begin{array}{c}-1.110 * * * \\
(-9.910)\end{array}$ & $\begin{array}{c}-1.046^{* * *} \\
(-9.491)\end{array}$ & $\begin{array}{c}-0.005 \\
(-0.544)\end{array}$ & $\begin{array}{c}-0.004 \\
(-0.484)\end{array}$ & $\begin{array}{c}-0.002 \\
(-0.221)\end{array}$ & $\begin{array}{c}-0.002 \\
(-0.183)\end{array}$ \\
\hline Net FA/TA ${ }_{t-1}$ & $\begin{array}{c}0.619 * * * \\
(2.726)\end{array}$ & $\begin{array}{c}0.672 * * * \\
(2.954)\end{array}$ & $\begin{array}{c}0.648 * * * \\
(2.846)\end{array}$ & $\begin{array}{c}0.077 \\
(1.197)\end{array}$ & $\begin{array}{c}0.076 \\
(1.179)\end{array}$ & $\begin{array}{c}0.072 \\
(1.129)\end{array}$ & $\begin{array}{c}0.071 \\
(1.110)\end{array}$ \\
\hline $\log ($ Firm age $)$ & $\begin{array}{c}1.075^{* * *} \\
(17.007)\end{array}$ & $\begin{array}{c}1.083^{* * *} \\
(16.998)\end{array}$ & $\begin{array}{c}1.066^{* * *} \\
(16.708)\end{array}$ & $\begin{array}{c}0.023 \\
(1.047)\end{array}$ & $\begin{array}{c}0.017 \\
(0.790)\end{array}$ & $\begin{array}{c}0.013 \\
(0.609)\end{array}$ & $\begin{array}{c}0.024 \\
(1.124)\end{array}$ \\
\hline Past volatility & $\begin{array}{c}-12.853 * * * \\
(-15.074)\end{array}$ & $\begin{array}{c}-12.823 * * * \\
(-14.961)\end{array}$ & $\begin{array}{c}-12.446 * * * \\
(-14.662)\end{array}$ & $\begin{array}{r}-0.151^{* *} \\
(-2.305)\end{array}$ & $\begin{array}{c}-0.139 * * \\
(-2.126)\end{array}$ & $\begin{array}{c}-0.132 * * \\
(-2.012)\end{array}$ & $\begin{array}{c}-0.144 * * \\
(-2.197)\end{array}$ \\
\hline Total IOR IOI $_{t-1}$ & $\begin{array}{c}-1.041 * * * \\
(-5.315)\end{array}$ & & & $\begin{array}{c}-0.019 \\
(-0.650)\end{array}$ & & & $\begin{array}{c}-0.138 * * * \\
(-3.220)\end{array}$ \\
\hline Top10ownt-1 & & $\begin{array}{c}-0.851 * * * \\
(-3.168)\end{array}$ & & & $\begin{array}{c}0.088^{* *} \\
(2.513)\end{array}$ & & \\
\hline Top10LTIO $_{t-1}$ & & & $\begin{array}{c}-0.384 \\
(-1.381)\end{array}$ & & & $\begin{array}{c}0.116^{* * *} \\
(3.094)\end{array}$ & $\begin{array}{c}0.240^{* * *} \\
(4.850)\end{array}$ \\
\hline Top10STIO $_{t-1}$ & & & $\begin{array}{c}-2.702 * * * \\
(-5.948)\end{array}$ & & & $\begin{array}{c}-0.051 \\
(-0.982)\end{array}$ & $\begin{array}{c}0.091 \\
(1.343)\end{array}$ \\
\hline Year fixed & Yes & Yes & Yes & Yes & Yes & Yes & Yes \\
\hline Industry fixed & Yes & Yes & Yes & No & No & No & No \\
\hline Firm fixed & No & No & No & Yes & Yes & Yes & Yes \\
\hline Industry-Year fixed & No & No & No & No & No & No & No \\
\hline Constant & $\begin{array}{c}-3.305^{* * *} \\
(-9.971) \\
\end{array}$ & $\begin{array}{c}-3.237 * * * \\
(-9.421) \\
\end{array}$ & $\begin{array}{c}-3.346^{* * * *} \\
(-9.864) \\
\end{array}$ & $\begin{array}{c}0.175 * * * \\
(2.763) \\
\end{array}$ & $\begin{array}{c}0.172 * * * \\
(2.804) \\
\end{array}$ & $\begin{array}{c}0.172 * * * \\
(2.801) \\
\end{array}$ & $\begin{array}{c}0.117^{*} \\
(1.827) \\
\end{array}$ \\
\hline $\begin{array}{l}\text { Partial F-test of } \\
\left(\text { Total IOR } \text { It- }^{+} \text {Top } 1\right.\end{array}$ & $\left.I O_{t-1}=0\right)$ & & & & & & $\begin{array}{c}7.14^{* * *} \\
(p=0.008)\end{array}$ \\
\hline $\begin{array}{l}\text { Observations } \\
R \text {-squared } \\
\left(\text { Pseudo } R^{2}\right) \\
\end{array}$ & $\begin{array}{c}22,526 \\
0.338\end{array}$ & $\begin{array}{c}22,526 \\
0.335\end{array}$ & $\begin{array}{c}22,526 \\
0.337\end{array}$ & $\begin{array}{c}22,414 \\
0.042\end{array}$ & $\begin{array}{c}22,414 \\
0.042\end{array}$ & $\begin{array}{c}22,414 \\
0.043\end{array}$ & $\begin{array}{c}22,414 \\
0.044\end{array}$ \\
\hline
\end{tabular}

Robust $z$ and $t$-statistics in parentheses

$* * * p<0.01, * * p<0.05, * p<0.1$

\subsection{Endogeneity and causality}

The endogenous nature of ownership makes it difficult to produce conclusive evidence on the effect of monitoring institutions on dividends (Demsetz and Lehn, 1985). We address this concern by estimating a change model similar to Moser and Puckett (2009) and an instrumental 
variable (IV) regression.

The change model includes the same variables as the level model in Column (7) of Table 2, but includes changes to examine how change in institutional ownership is related to future dividend payouts. We report the results in Columns (1)-(2) in Table 3. In Column (1), we regress the change in dividend payout ratio that is calculated based on net income between year $t$ and $t+1$ on change in Top10LTIO between year $t-1$ and $t$ and the changes in other explanatory variables between year $t-1$ and $t$. In Column (2), we regress the change in dividend payout that is calculated based on net income before extraordinary items between year $t$ and $t+1$ on change in Top10LTIO between year $t-1$ and $t$ and the changes in other explanatory variables between year $t-1$ and $t$. The results show that an increase in lagged Top10LTIO is associated with an increase in dividend payouts when we control for year and industry fixed effects, supporting Hypothesis 1.

The $R$-squared from change models on the relation between institutional ownership and dividends is usually low, ranging from less than $1 \%$ in Grinstein and Michaely (2005) to 3\% in Hartzell and Starks (2003). Moser and Puckett (2009) include additional control variables like changes in Beta, changes in market to book ratio, etc. and their $R$-squared is close to $5 \%$ as well. Even though the $R$-squared from our change models is less than $5 \%$, it is in line with the previous studies. 
Table 3. Future dividend payout change regression

Table 3 reports the relation between change in future dividend payout and various types of institutional ownership change. The sample is restricted to firm-years with $N I_{t}$ and $N I_{t-1}>0$. All model standard errors are robust standard errors clustered at the firm level.

\begin{tabular}{|c|c|c|}
\hline VARIABLES & $\begin{array}{c}(1) \\
\Delta\left(\operatorname{Div}_{t+1} / N I_{t}\right) \\
\end{array}$ & $\begin{array}{c}(2) \\
\Delta\left(\operatorname{Div}_{t+1} / I B_{t}\right) \\
\end{array}$ \\
\hline$\triangle \log (M V)_{t}$ & $\begin{array}{l}0.021 * * \\
(2.342)\end{array}$ & $\begin{array}{c}0.015 \\
(1.562)\end{array}$ \\
\hline$\Delta$ Leverage $_{t}$ & $\begin{array}{c}-0.174 * * * \\
(-3.452)\end{array}$ & $\begin{array}{c}-0.217 * * * \\
(-3.954)\end{array}$ \\
\hline$\Delta \mathrm{Cash} / \mathrm{TA} A_{t}$ & $\begin{array}{l}0.123 * * \\
(2.480)\end{array}$ & $\begin{array}{c}0.155 * * * \\
(2.582)\end{array}$ \\
\hline$\triangle R O A_{t}$ & $\begin{array}{c}-1.987 * * * \\
(-13.504)\end{array}$ & $\begin{array}{c}-1.949 * * * \\
(-12.325)\end{array}$ \\
\hline$\triangle$ Sale's Growth $_{t}$ & $\begin{array}{c}-0.009 \\
(-0.579)\end{array}$ & $\begin{array}{c}0.006 \\
(0.364)\end{array}$ \\
\hline$\triangle \mathrm{Net} F A / T A_{t}$ & $\begin{array}{c}0.047 \\
(0.413)\end{array}$ & $\begin{array}{c}0.057 \\
(0.480)\end{array}$ \\
\hline $\log (\text { Firm age })_{t}$ & $\begin{array}{c}0.003 \\
(1.073)\end{array}$ & $\begin{array}{c}0.001 \\
(0.191)\end{array}$ \\
\hline$\triangle$ Past volatility $_{t}$ & $\begin{array}{c}-0.123 \\
(-1.430)\end{array}$ & $\begin{array}{c}-0.139 \\
(-1.532)\end{array}$ \\
\hline$\Delta$ Total IOR & $\begin{array}{c}-0.035 \\
(-0.692)\end{array}$ & $\begin{array}{c}-0.001 \\
(-0.013)\end{array}$ \\
\hline$\triangle$ Top10LTIO $_{t}$ & $\begin{array}{l}0.155^{* *} \\
(2.403)\end{array}$ & $\begin{array}{l}0.117^{*} \\
(1.722)\end{array}$ \\
\hline$\triangle$ ToplOSTIO $_{t}$ & $\begin{array}{c}0.019 \\
(0.241)\end{array}$ & $\begin{array}{c}-0.019 \\
(-0.239)\end{array}$ \\
\hline $\begin{array}{l}\text { Year fixed } \\
\text { Industry fixed }\end{array}$ & $\begin{array}{l}\text { Yes } \\
\text { Yes }\end{array}$ & $\begin{array}{l}\text { Yes } \\
\text { Yes }\end{array}$ \\
\hline $\begin{array}{l}\text { Partial } F \text {-test of } \\
\left(\Delta \text { Total IOR }+\Delta \text { Top } 10 L T I O_{\mathrm{t}}=0\right)\end{array}$ & $\begin{array}{c}5.29 * * \\
(p=0.022)\end{array}$ & $\begin{array}{l}9.65^{* * *} \\
(p=0.002)\end{array}$ \\
\hline Overall $F$-statistic & $19.73 * * *$ & $21.61 * * *$ \\
\hline $\begin{array}{l}\text { Observations } \\
R \text {-squared }\end{array}$ & $\begin{array}{c}16,455 \\
0.040\end{array}$ & $\begin{array}{c}16,455 \\
0.031\end{array}$ \\
\hline
\end{tabular}

Robust $t$-statistics in parentheses

$* * * p<0.01, * * p<0.05,{ }^{*} p<0.1$

Next, we introduce two instruments similar to Jiraporn, Jiraporn, Boeprasert, and Chang (2014). These instruments are both related to Top10LTIO and are not driven by firm-specific characteristics:

(1) Annual mean Top10LTIO of all other firms in the same two-digit zip area (Zip2Top10LTIO); and

(2) Mean Top10LTIO of all other firms that are in the same industry (FF48 Top 10LTIO) of 
the 48 industries defined by Fama and French (1997).

A valid IV must meet two criteria. It must affect the value of Top10LTIO and it must not affect firm performance through channels other than its direct effect on Top10LTIO. Due to certain shared-location-related influence, the Zip2Top10LTIO of all other firms in the same twodigit zip area should be positively correlated with that of a specific firm. For example, an industry cluster (a group of firms in the same industry that cluster geographically, Krugman, 1991), may attract long-term institutional investors that have favorable opinions about the longterm prospects of that industry. In the local bias literature, Hochberg and Rauh (2013) show that state politicians' influence on public pension funds leads to the overweighting of private equity investments in the home state.

If the Top10LTOwners own a large stake in a firm for industry-related reasons, FF48top10LTIO should be positively correlated with Top10LTIO. The first stage IV regression shows that our two instruments are not weak as they have an $F$-statistic of 19.44 ( $p$-value $=$ 0.000) (Stock and Yogo, 2005). An endogeneity test suggests that Top10LTIO is endogenous ( $p$ value $=0.003)$. Hansen's $J$-test shows that at least one of the instruments in the IV regression is valid $(p$-value $=0.668)$. The estimated coefficient of Top10LTIO is positive and significant, suggesting a $1.21 \%$ rise in dividend payouts for a $1 \%$ increase in the predicted Top 10 LTIO. The results from the two stages of the IV regression are reported in Table 4. The results in the second stage confirm the positive relation between Top10LTIO and the dividend payout ratio, which is both statistically and economically significant. 
Table 4. Instrumental variable regression

IV regression is estimated using a two-stage least squares regression and the dependent variable in the first stage is Top10LTIO. There are two instruments: the first instrument is Zip2 Top10LTIO, based on geographical location (with same two-digit zip codes) and the second instrument is FF48Top10LTIO, based on industry (within the same industry of the 48 as defined in Fama and French, 1997). The dependent variable in the second stage is $D i v_{t} / N I_{t-1}$. Both stages control for year and industry fixed effects and all model standard errors are robust standard errors clustered at the firm level.

\begin{tabular}{|c|c|c|}
\hline VARIABLES & $\begin{array}{c}(1) \\
\text { First Stage } \\
\text { Top10LTIO }\end{array}$ & $\begin{array}{c}(2) \\
\text { Second Stage } \\
\operatorname{Div}_{t} / N_{t-1}\end{array}$ \\
\hline Top10LTIO & & $\begin{array}{l}1.209^{* *} \\
(2.491)\end{array}$ \\
\hline $\log (M V)_{t}$ & $\begin{array}{c}0.025^{* * *} \\
(24.03)\end{array}$ & $\begin{array}{c}-0.020 \\
(-1.633)\end{array}$ \\
\hline Leverage $_{t}$ & $\begin{array}{l}0.015 \\
(1.54)\end{array}$ & $\begin{array}{c}-0.015 \\
(-0.490)\end{array}$ \\
\hline Cash/TA ${ }_{t}$ & $\begin{array}{c}-0.018^{*} \\
(-1.74)\end{array}$ & $\begin{array}{c}0.090 * * * \\
(2.853)\end{array}$ \\
\hline$R O A_{t}$ & $\begin{array}{c}-0.064 * * * \\
(-6.15)\end{array}$ & $\begin{array}{c}0.013 \\
(0.306)\end{array}$ \\
\hline Sale's Growth $t$ & $\begin{array}{c}-0.039 * * * \\
(-12.99)\end{array}$ & $\begin{array}{c}0.036 \\
(1.597)\end{array}$ \\
\hline Net FA/TA ${ }_{t}$ & $\begin{array}{c}-0.020^{* *} \\
(-2.18)\end{array}$ & $\begin{array}{c}0.130 * * * \\
(4.387)\end{array}$ \\
\hline $\log$ (Firm age) & $\begin{array}{c}-0.011 * * * \\
(-5.32)\end{array}$ & $\begin{array}{l}0.094 * * * \\
(11.363)\end{array}$ \\
\hline Past volatility & $\begin{array}{c}-0.313 * * * \\
(-13.50)\end{array}$ & $\begin{array}{c}-0.177 \\
(-1.052)\end{array}$ \\
\hline Instruments: & & \\
\hline Zip2 Top10LTIO & $\begin{array}{c}0.049 * * * \\
(5.22)\end{array}$ & \\
\hline FF48 Top10LTIO & $\begin{array}{c}0.068^{* * * *} \\
(2.91)\end{array}$ & \\
\hline Constant & $\begin{array}{c}0.068 * * * \\
(2.91)\end{array}$ & $\begin{array}{c}-0.029 \\
(-0.277) \\
\end{array}$ \\
\hline$F$-tests of excluded instruments & $\begin{array}{l}19.44 * * * \\
(p=0.000)\end{array}$ & \\
\hline Endogenous Chi-square test & $\begin{array}{c}8.761 \\
(p=0.003)\end{array}$ & \\
\hline Hansen's $J$-test & $\begin{array}{c}0.184 \\
(p=0.668)\end{array}$ & \\
\hline $\begin{array}{l}\text { Observations } \\
R^{2}\end{array}$ & $\begin{array}{c}26,401 \\
0.308 \\
\end{array}$ & $\begin{array}{c}26,401 \\
0.057 \\
\end{array}$ \\
\hline
\end{tabular}

Robust $t$ (the first equation) and $z$-statistics (the second equation) in parentheses $* * * p<0.01, * * p<0.05, * p<0.1$ 


\section{Effect of the Top10LTOwners on dividend payouts and agency costs}

\subsection{Firm-level agency costs, the Top10LTOwners, and dividend payouts}

To test Hypothesis 2a, we proxy agency costs with (1) positive free cash flow with poor investment opportunities and (2) the magnitude of earnings management. The measure of free cash flow is adapted from Lang, Stulz, and Walkling (1991). It is calculated as operating income before depreciation minus income taxes, increases in deferred tax, and investment tax credit and interest expenses. We do not subtract dividends to calculate free cash flow as this paper investigates the effect of institutional monitoring on dividends. However, our results remain qualitatively the same if the free cash flow measure excludes cash flow for dividends. We use Tobin's Q as a proxy for investment opportunities and define poor investment opportunities as $\mathrm{Q}$ less than 1, following Lang, Stulz, and Walkling (1991).

Similar to Chung, Firth, and Kim (2002), our measure of earnings management follows the modified Jones model (1991). Previous studies claim that this model is the most powerful in detecting earnings management between competing models (Dechow, Sloan, and Sweeney, 1995) and is both effective (Davidson, Jiraporn, Kim, and Nemec, 2004) and reliable (Guay, Kothari, and Watts, 1996). We calculate the difference between reported earnings and operating cash flows as our measure of accruals. We also estimate the expected accruals by regressing total accruals of all firms in an industry with the same 2-digit SIC code on firm characteristics that may influence accruals: total assets; revenue; property, plant, and equipment; and accounts receivable.

We report the results for two subsamples, firms with positive free cash flow and Tobin's Q less than 1, and firms with positive free cash flow and Tobin's Q greater than or equal to 1, in Columns (1) and (2) of Panel A in Table 5. The positively significant partial $F$-statistic in Column (1) tells us that the Top10LTOwners are positively associated with higher dividend 
payouts only in firms with both positive free cash flow and low Q. We also report the results on the relation between the Top10LTOwners and firms with above- and below-median earnings management, in Columns (3) and (4), respectively. As expected and shown by the highly significant partial $F$-statistic in Column (3), the positive relation between the Top10LTOwners and dividend payouts only exists in firms with higher absolute magnitudes of earnings management. Higher proportion of the Top10 short-term owners does not lead to dividend payout increases, as suggested by the either insignificant or negative joint effect of Total IOR and Top10STIO. Our findings provide support for Hypotheses 2a and 2b, suggesting that concentrated long-term institutional ownership leads to higher dividend payouts only at firms with high agency costs.

\subsection{Top10LTOwners, external monitoring mechanisms, and dividend payouts}

We use product market competition and the quality of access to public information in the state where the firm's headquarters are located as proxies for external monitoring mechanisms. Similar to Jurkus, Park, and Woodard (2011), we construct the Herfindahl concentration index, which is calculated as the sum of the squared market shares, as the measure of product market competition:

$$
H H I_{j t}=\sum_{i=1}^{N_{j}} S_{i j t}^{2}
$$

where $S_{i j t}$ is the market share of firm $i$ in industry $j$ in year $t$ and firms with the same three-digit SIC codes are assumed to belong to the same industry. We calculate market shares based on firms' sales using Compustat data and exclude firms for which sales are either missing or negative.

Different states have different regulations and policies on public access to information and therefore present different external governance and informational environments for 
businesses. The Center for Public Integrity (www.publicintegrity.org) collects data in a number of categories that reflect the quality of corporate governance and transparency, such as access to public information, executive accountability, and legislative accountability, and report scores for each state. The ranks of state-level governance from the scoring system are highly correlated with those reported by Glaeser and Saks (2006) and Hochberg and Rauh (2013). We use this scoring system as our second proxy for the strength of external monitoring.

We estimate the relation between the Top10LTOwners and the dividend payout ratio in two sets of subsamples, firms with above- and below-median HHI values and firms with aboveand below-median ranks of the quality of access to public information in the state where the firm's headquarters are located. We report the results in Panel B of Table 5. As suggested by the highly significant partial $F$-statistics in Columns (1) and (4), the Top10LTOwners are positively associated with the dividend payout ratio in the subsamples with weaker external monitoring systems, that is, firms in an industry with low competition or firms located in a state with poor access to public information. When strong external monitoring systems are in place, the Top10LTOwners are not associated with the dividend payout ratio. Our findings provide support for Hypotheses $3 \mathrm{a}$ and $3 \mathrm{~b}$. 
Table 5. Institutional ownership and dividend payout: severity of agency problems

Panel A. Free cash flow and earnings management as a proxy for severity of agency problems

Firms in Columns (1) and (3) are likely to have more severe agency problems while firms Columns (2) and (4) are not.

\begin{tabular}{|c|c|c|c|c|}
\hline & $(1)$ & $(2)$ & (3) & (4) \\
\hline \multirow[t]{4}{*}{ VARIABLES } & $\operatorname{Div}_{t} / N I_{t-1}$ & $\operatorname{Div}_{t} / N I_{t-1}$ & $\operatorname{Div}_{t} / N I_{t-1}$ & $\operatorname{Div}_{t} / N I_{t-1}$ \\
\hline & Positive Free & Positive Free & High & Low \\
\hline & Cash Flow & Cash Flow & Earnings & Earnings \\
\hline & Low Tobin's Q & High Tobin's Q & Management & Management \\
\hline \multirow[t]{2}{*}{ Total IOR ${ }_{t-1}$} & -0.141 & $-0.158 * * *$ & $-0.103 *$ & $-0.200 * * *$ \\
\hline & $(-0.908)$ & $(-2.960)$ & $(-1.930)$ & $(-2.837)$ \\
\hline \multirow[t]{2}{*}{ Top10LTIO $_{t-1}$} & $0.404 * *$ & $0.174 * * *$ & $0.234 * * *$ & $0.237 * * *$ \\
\hline & $(2.026)$ & $(2.858)$ & $(3.436)$ & $(3.103)$ \\
\hline \multirow[t]{2}{*}{ Top10STIO $_{t-1}$} & -0.080 & 0.116 & 0.042 & 0.054 \\
\hline & $(-0.338)$ & (1.374) & $(0.445)$ & $(0.497)$ \\
\hline Financial variables & Yes & Yes & Yes & Yes \\
\hline \multicolumn{5}{|l|}{ Controlled } \\
\hline Year fixed & Yes & Yes & Yes & Yes \\
\hline Firm fixed & Yes & Yes & Yes & Yes \\
\hline Partial $F$-test of & $F=4.85 * *$ & $F=0.11$ & $F=5.94 * *$ & $F=0.37$ \\
\hline$\left(\right.$ Total IOR It- $^{+}$ & $(p=0.028)$ & $(p=0.738)$ & $(p=0.015)$ & $(p=0.546)$ \\
\hline \multicolumn{5}{|l|}{ Top10LTIO $_{t-1}=0$ ) } \\
\hline Overall $F$-statistic & $F=2.94 * * *$ & $F=11.09 * * *$ & $F=5.99 * * *$ & $F=9.57 * * *$ \\
\hline Observations & 3071 & 15163 & 10458 & 11956 \\
\hline$R$-squared & 0.081 & 0.049 & 0.033 & 0.063 \\
\hline
\end{tabular}

Robust $t$-statistics in parentheses

$* * * p<0.01, * * p<0.05, * p<0.1$ 
Panel B. Other monitoring mechanisms that influence the severity of agency problems

Firms in Columns (2) and (3) have stronger external monitoring systems while firms in Columns (1) and (4) do not.

\begin{tabular}{|c|c|c|c|c|}
\hline VARIABLES & $\begin{array}{c}\text { (1) } \\
\operatorname{Div}_{t} / N I_{t-1} \\
\text { High HHI }\end{array}$ & $\begin{array}{c}(2) \\
D i v_{t} / N I_{t-1} \\
\text { Low HHI }\end{array}$ & $\begin{array}{c}(3) \\
D i v_{t} / N I_{t-1} \\
\text { Better access to } \\
\text { State public info }\end{array}$ & $\begin{array}{c}(4) \\
D i v_{t} / N I_{t-1} \\
\text { Worse access to } \\
\text { State public info }\end{array}$ \\
\hline Total IOR ${ }_{t-1}$ & $\begin{array}{l}-0.123^{*} \\
(-1.832)\end{array}$ & $\begin{array}{l}-0.112 * * \\
(-2.060)\end{array}$ & $\begin{array}{c}-0.232 * * * \\
(-3.172)\end{array}$ & $\begin{array}{l}-0.062 \\
(-1.058)\end{array}$ \\
\hline Top10LTIO $_{t-1}$ & $\begin{array}{c}0.269 * * * \\
(3.514)\end{array}$ & $\begin{array}{l}0.150 * * \\
(2.406)\end{array}$ & $\begin{array}{c}0.285^{* * *} \\
(4.001)\end{array}$ & $\begin{array}{c}0.201 * * * \\
(2.669)\end{array}$ \\
\hline Top10STIO $_{t-1}$ & $\begin{array}{c}0.029 \\
(0.280)\end{array}$ & $\begin{array}{l}0.147^{*} \\
(1.668)\end{array}$ & $\begin{array}{c}0.097 \\
(0.943)\end{array}$ & $\begin{array}{c}0.088 \\
(0.920)\end{array}$ \\
\hline $\begin{array}{l}\text { Financial variables } \\
\text { controlled }\end{array}$ & Yes & Yes & Yes & Yes \\
\hline Year fixed & Yes & Yes & Yes & Yes \\
\hline Industry fixed & No & No & No & No \\
\hline Firm fixed & Yes & Yes & Yes & Yes \\
\hline Partial $F$-test of & $F=7.43 * * *$ & $F=0.42$ & $F=0.84$ & $F=6.74 * * *$ \\
\hline $\begin{array}{l}\left(\text { Total IOR }_{t-1}+\right. \\
\left.\text { Top10LTIO }_{t-1}=0\right)\end{array}$ & $(p=0.007)$ & $(p=0.515)$ & $(p=0.361)$ & $(p=0.010)$ \\
\hline Overall $F$-statistic & $F=9.01 * * *$ & $F=5.96 * * *$ & $F=7.79 * * *$ & $F=6.08 * * *$ \\
\hline Observations & 12088 & 10325 & 10512 & 10407 \\
\hline$R$-squared & 0.058 & 0.034 & 0.045 & 0.044 \\
\hline
\end{tabular}

Robust $t$-statistics in parentheses

$* * * p<0.01, * * p<0.05, * p<0.1$

\section{Robustness}

Although our results are consistent with hypotheses based on agency theory, tax and clientele effects have long been thought to influence the relationship between institutional ownership and dividend payouts. An alternative explanation for our results is that the positive relation between Top10LTOwners and dividend payouts is due to the 2003 dividend tax cut, as firms that already pay dividends increased the amount after the tax cut (Chetty and Saez, 2006). We investigate this alternative by dividing our sample into observations from before and after 2003. We re-estimate the relation and report the results in Columns (1) and (2) of Table 6. The coefficient estimates for Top10LTIO in both before- and after-2003 subsamples are positive and significant, alleviating the concern that our findings are driven by the change in the tax law. 
We conduct further robustness checks using alternative measures of the dividend payout ratio. We examine the alternative dividend measures of total payouts, dividends for common/ordinary shares, and cash dividends and report these results in Columns (3)-(8) in Table 6. We normalize the dividend amount by alternative income measures, including $I B, E B I T$ instead of $N I$ and find the relation between Top10LTIO and the alternative dividend payout measures to remain positive and significant. We also calculate the dividend yield, which is the dividend per share in year $t$ divided by price per share in year $t-1$ to estimate the relation between Top10LTIO and the dividend yield. The relation between the Top10LTOwners and dividend yield remains positive, but insignificant at the conventional level according to the $F$-statistics. The differential relation between the Top10LTOwners on income- and market value-based dividend payout measures suggests that income is an important condition that the Top10LTOwners consider when they use dividend payout as a monitoring tool, consistent with our argument in Section 3.1. Even though they are not tabulated, our results are also robust to normalizing cash dividends or common dividends by contemporaneous net income.

Institutions may have different clientele due to their different tax advantages. For example, despite the institutions' similar investment horizons, the clientele attracted to pension funds is usually different from that to mutual funds. We investigate the clientele effect due to the tax advantages of pension funds by excluding pension funds from the Top10LTOwners. The results still hold, suggesting that our results are not driven by the clientele effect. 
Table 6. Sub-period and robustness tests

Columns (1) - (2) present results from pre-2002 and post-2003 sub-periods, respectively. The dependent variables in Columns (3) - (8) are alternative measures of dividend payout.

\begin{tabular}{|c|c|c|c|c|c|c|c|c|}
\hline VARIABLES & $\begin{array}{c}(1) \\
\operatorname{Div}_{t} / N I_{t-1} \\
<=2002\end{array}$ & $\begin{array}{c}(2) \\
\operatorname{Div}_{t} / N I_{t-1} \\
\geq=2003\end{array}$ & $\begin{array}{c}(3) \\
D i v_{t} / I B_{t-1}\end{array}$ & $\begin{array}{c}(4) \\
\operatorname{Div}_{t} / E B I T_{t-1}\end{array}$ & $\begin{array}{c}(5) \\
D v c_{t} / N I_{t}\end{array}$ & $\begin{array}{c}(6) \\
\text { Div }_{t} / M_{k t c a p}\end{array}$ & $\begin{array}{c}\text { (7) } \\
\text { Div Yield } t\end{array}$ & $\begin{array}{c}(8) \\
\text { Totpay }_{t} / N I_{t-1}\end{array}$ \\
\hline Total IOR $\mathrm{t}-1$ & $\begin{array}{l}-0.040 \\
(-0.705)\end{array}$ & $\begin{array}{c}-0.106 \\
(-1.598)\end{array}$ & $\begin{array}{c}-0.145^{* * *} \\
(-3.323)\end{array}$ & $\begin{array}{c}-0.064 * * * \\
(-3.173)\end{array}$ & $\begin{array}{c}-0.139 * * * \\
(-3.927)\end{array}$ & $\begin{array}{c}-0.004 * * * \\
(-2.783)\end{array}$ & $\begin{array}{c}-0.003 * * * \\
(-2.696)\end{array}$ & $\begin{array}{c}-0.135 \\
(-0.968)\end{array}$ \\
\hline Top10LTIO $\mathrm{t}-1$ & $\begin{array}{c}0.195^{* * * *} \\
(2.610)\end{array}$ & $\begin{array}{c}0.242 * * * \\
(3.336)\end{array}$ & $\begin{array}{c}0.234 * * * \\
(4.510)\end{array}$ & $\begin{array}{c}0.102 * * * \\
(4.161)\end{array}$ & $\begin{array}{c}0.213 * * * \\
(4.782)\end{array}$ & $\begin{array}{c}0.005^{* * *} \\
(3.420)\end{array}$ & $\begin{array}{c}0.004 * * * \\
(3.093)\end{array}$ & $\begin{array}{c}0.501 * * * \\
(2.970)\end{array}$ \\
\hline Top10STIO $\mathrm{t}-1$ & $\begin{array}{c}0.042 \\
(0.417)\end{array}$ & $\begin{array}{c}0.087 \\
(0.860)\end{array}$ & $\begin{array}{c}0.078 \\
(1.154)\end{array}$ & $\begin{array}{l}0.059^{*} \\
(1.880)\end{array}$ & $\begin{array}{c}0.133 * * \\
(2.438)\end{array}$ & $\begin{array}{l}0.004 * * \\
(2.147)\end{array}$ & $\begin{array}{l}0.003^{*} \\
(1.850)\end{array}$ & $\begin{array}{l}-0.421^{* *} \\
(-2.028)\end{array}$ \\
\hline $\begin{array}{l}\text { Financial variables } \\
\text { Controlled }\end{array}$ & Yes & Yes & Yes & Yes & Yes & Yes & Yes & Yes \\
\hline Year fixed & Yes & Yes & Yes & Yes & Yes & Yes & Yes & Yes \\
\hline Industry fixed & No & No & No & No & No & No & No & No \\
\hline Firm fixed & Yes & Yes & Yes & Yes & Yes & Yes & Yes & Yes \\
\hline $\begin{array}{l}\text { Partial F-test of } \\
(\text { Total IOR } \mathrm{t}-1+ \\
\left.\text { Top10LTIO }{ }_{\mathrm{t}-1}=0\right)\end{array}$ & $\begin{array}{l}10.52 * * * \\
(p=0.001)\end{array}$ & $\begin{array}{c}4.15^{* *} \\
(p=0.042)\end{array}$ & $\begin{array}{c}5.06^{* *} \\
(p=0.025)\end{array}$ & $\begin{array}{c}4.16^{* *} \\
(p=0.042)\end{array}$ & $\begin{array}{c}4.75^{* *} \\
(p=0.029)\end{array}$ & $\begin{array}{c}1.43 \\
(p=0.233)\end{array}$ & $\begin{array}{c}0.94 \\
(p=0.332)\end{array}$ & $\begin{array}{c}8.42 * * * \\
(p=0.004)\end{array}$ \\
\hline Observations & 10,791 & 11,623 & 22,414 & 22,414 & 21,871 & 22,414 & 22,575 & 20,378 \\
\hline$R$-squared & 0.059 & 0.036 & 0.039 & 0.027 & 0.018 & 0.043 & 0.049 & 0.044 \\
\hline
\end{tabular}

Robust $t$-statistics in parentheses

$* * * p<0.01, * * p<0.05, * p<0.1$

We conduct further robustness checks on the effect of Top10LTOwners on dividend payouts. We identify long-term institutional ownership based on the churn rate (turnover ratio) of each institution following Gaspar, Massa, and Matos (2005). We also include another type of majority ownership, block holder ownership, as a control as these owners have been shown to play a role in agency costs (Ang, Cole, and Lin, 2000). The positive relation between the Top10LTOwners and dividend payouts from these additional checks remains unchanged.

\section{Discussion and conclusion}

Although agency theory predicts that monitoring institutional owners will push for higher dividend payouts as these payouts are an effective, credible monitoring device, empirical evidence for this prediction has been mixed. Heterogeneity in institutional ownership may have driven this mixed evidence, as different institutions have different incentives and vary in their 
choices between trading and monitoring. Alternatively, monitoring institutional investors may condition their use of dividend payouts to mitigate agency problems on firms' financial performance and we show that the firms' income is an important conditioning variable. We test the joint hypothesis that concentrated institutional investors with both large stakes and long investment horizons monitor, and that they monitor through the dividend payout channel. We find supporting evidence that is consistent with this hypothesis. We show that the positive relationship is only salient for firms with high agency costs and weak external monitoring systems, suggesting that institutions will only monitor when they foresee improved benefits from doing so.

Future research could explore other characteristics of institutional ownership that monitors, the conditions that influence institutional investors' choice of monitoring tools, and how different types of institutional ownership, such as mutual funds or pension funds, influence dividend payouts. This work could also be extended by investigating how other monitoring mechanisms that are already in place affect institutional investors' monitoring incentives. 


\section{References}

Allen, F., Bernardo, A. E., \& Welch, I. (2000). A theory of dividends based on tax clienteles. Journal of Finance, 55(6), 2499-2536.

Ang, J. S., Cole, R. A., \& Lin, J. W. (2000). Agency costs and ownership structure. Journal of Finance, 55(1), 81-106.

Beyer, A., Larcker, D., \& Tayan, B. (2014). Study on how investment horizon and expectations of shareholder base impact corporate decision-making. National Investor Relations Institute and The Rock Center for Corporate Governance.

Brav, A., Graham, J. R., Harvey, C. R., \& Michaely, R. (2005). Payout policy in the 21st century. Journal of Financial Economics, 77(3), 483-527.

Burns, N., Kedia, S., \& Lipson, M. (2010). Institutional ownership and monitoring: Evidence from financial misreporting. Journal of Corporate Finance, 16(4), 443-455.

Bushee, B. J. (1998). The influence of institutional investors on myopic R\&D investment behavior. Accounting Review, 73(3) 305-333.

Carleton, W. T., Nelson, J. M., \& Weisbach, M. S. (1998). The Influence of Institutions on Corporate Governance through Private Negotiations: Evidence from TIAA-CREF. The Journal of Finance, 53(4), 1335-1362.

Chen, X., Harford, J., \& Li, K. (2007). Monitoring: Which institutions matter? Journal of Financial Economics, 86(2), 279-305.

Chetty, R., \& Saez, E. (2006). The effects of the 2003 dividend tax cut on corporate behavior: Interpreting the evidence. American Economic Review, 96, 124-129.

Chung, R., Firth, M., \& Kim, J. B. (2002). Institutional monitoring and opportunistic earnings management. Journal of Corporate Finance, 8(1), 29-48.

Chung, R., Firth, M., \& Kim, J. B. (2005). Earnings management, surplus free cash flow, and external monitoring. Journal of Business Research, 58(6), 766-776.

Cornett, M.M., Marcus, A. J., and Tehranian, H. (2008). Corporate governance and pay-forperformance: The impact pf earnings management. Journal of Financial Economics, 87, 357373.

Crane, A. D., Michenaud, S., \& Weston, J. P. (2014). The effect of institutional ownership on payout policy: evidence from index thresholds. Working paper, Rice University.

Davidson, W. N., Jiraporn, P., Kim, Y. S., \& Nemec, C. (2004). Earnings management following duality-creating successions: Ethnostatistics, impression management, and agency theory. Academy of Management Journal, 47(2), 267-275.

DeAngelo, H., DeAngelo, L., \& Stulz, R. M. (2006). Dividend policy and the earned/contributed capital mix: a test of the life-cycle theory. Journal of Financial Economics, 81(2), 227-254.

Dechow, P. M., Sloan, R. G., \& Sweeney, A. P. (1995). Detecting earnings management. Accounting Review, 70(2), 193-225.

Demsetz, H., \& Lehn, K. (1985). The structure of corporate ownership: Causes and consequences. Journal of Political Economy, 93(6), 1155-1177.

Easterbrook F. H. (1984). Two agency-cost explanations of dividends. American Economic Review 74, 650-59.

Fama, E. F., \& French, K. R. (1997). Industry costs of equity. Journal of Financial Economics, 43(2), 153-193.

Farre-Mensa, J., Michaely, R., \& Schmalz, M. (2014). Payout Policy. Annual Review of Financial Economics, 6, 75-134. 
Gaspar, J. M., Massa, M., \& Matos, P. (2005). Shareholder investment horizons and the market for corporate control. Journal of Financial Economics, 76(1), 135-165.

Glaeser, E. L., \& Saks, R. E. (2006). Corruption in America. Journal of Public Economics, 90(6), 1053-1072.

Giroud, X., \& Mueller, H. M. (2010). Does corporate governance matter in competitive industries?. Journal of Financial Economics, 95(3), 312-331.

Grinstein, Y., \& Michaely, R. (2005). Institutional holdings and payout policy. Journal of Finance, 60(3), 1389-1426.

Grossman S. J., \& Hart, O.D. (1980). Takeover bids, the free-rider problem, and the theory of the corporation. Bell Journal of Economics, 11, 42-54.

Grullon, G., \& Michaely, R. (2012). Corporate payout policy and product market competition. Working Paper, Rice University.

Guay, W. R., Kothari, S. P., \& Watts, R. L. (1996). A market-based evaluation of discretionary accrual models. Journal of Accounting Research, 34, 83-105.

Harford, J., Kecskes, A., \& Mansi, S. (2014). Do long-term investors improve corporate decision making? Working paper, University of Washington.

Hart, O. D. (1983). The market mechanism as an incentive scheme. Bell Journal of Economics, $14,366-382$.

Hartzell, J. C., \& Starks, L. T. (2003). Institutional investors and executive compensation. The Journal of Finance, 58(6), 2351-2374.

Hochberg, Y. V., \& Rauh, J. D. (2013). Local overweighting and underperformance: evidence from limited partner private equity investments. Review of Financial Studies, 26(2), 403-451.

Hoberg, G., Phillips, G., \& Prabhala, N. (2014). Product market threats, payouts, and financial flexibility. Journal of Finance, 69(1), 293-324.

Holmstrom, B. (1982). Moral hazard in teams. Bell Journal of Economics, 13(2), 324-340.

Jensen, M. C. (1986). Agency costs of free cash flow, corporate finance, and takeovers. The American Economic Review, 76, 323-329.

Jiraporn, P., Jiraporn, N., Boeprasert, A. \& Chang, K. (2014). Does Corporate Social Responsibility (CSR) Improve Credit Ratings? Evidence from Geographic Identification. Financial Management, 43, 505-531.

John, K., \& Knyazeva, A. (2006). Payout policy, agency conflicts, and corporate governance. Unpublished working paper, New York University.

John, K., Knyazeva, A. \& Knyazeva, D. (2011). Does geography matter? Firm location and corporate payout policy. Journal of Financial Economics, 101(3), 533-551.

Jones, J. J. (1991). Earnings management during import relief investigations. Journal of Accounting Research, 29, 193-228.

Jurkus, A. F., Park, J. C., \& Woodard, L. S. (2011). Women in top management and agency costs. Journal of Business Research, 64(2), 180-186.

Kennedy, P. (1996). A Guide to Econometrics, 4th edition, Blackwell.

Khan, R., Dharwadkar, R., \& Brandes, P. (2005). Institutional ownership and CEO compensation: a longitudinal examination. Journal of Business Research, 58(8), 1078-1088.

Krugman, P. R. (1991). Geography and trade, MIT press.

Lang, L. H., Stulz, R., \& Walkling, R. A. (1991). A test of the free cash flow hypothesis: The case of bidder returns. Journal of Financial Economics, 29(2), 315-335.

Moser, W. and Puckett, A. (2009). "Dividend Tax Clienteles: Evidence from tax law changes" Journal of American Taxation Association, 31 (1), 1-22. 
Nalebuff, B. J., \& Stiglitz, J. E. (1983). Information, competition, and markets. American Economic Review, 73(2), 278-283.

Officer, M. S. (2011). Overinvestment, corporate governance, and dividend initiations. Journal of Corporate Finance, 17(3), 710-724.

Stock, J. H., \& Yogo, M. (2005). Testing for weak instruments in linear IV regression. Identification and inference for econometric models: Essays in honor of Thomas Rothenberg.

Velury, U., \& Jenkins, D. S. (2006). Institutional ownership and the quality of earnings. Journal of Business Research, 59(9), 1043-1051. 
Appendix. Variable definitions and data sources

\begin{tabular}{|c|c|c|}
\hline Variable Name & Definition & Source \\
\hline \multicolumn{3}{|l|}{ Financial variables } \\
\hline$\overline{D i v_{t} / N I_{t-1}}$ & $\begin{array}{l}D I V \text { is total amount of cash dividends paid } \\
\text { for common and preferred stocks. NI is net } \\
\text { income. }\end{array}$ & Compustat \\
\hline Div Dum & $\begin{array}{l}\text { Dividend dummy variable. Equals one if } \\
\text { firms pay cash dividends, else } 0 .\end{array}$ & Compustat \\
\hline$\overline{D i v_{t} / I B_{t-1}}$ & $I B$ is net income before extraordinary items & Compustat \\
\hline$\overline{D i v_{t} / E B I T_{t-1}}$ & $E B I T$ is earnings before interests and taxes & Compustat \\
\hline $\operatorname{Div}_{t} /$ Mktcap $_{t-1}$ & Mktcap is market value of common stock & Compustat \\
\hline Div Yield $_{t}$ & $\begin{array}{l}\text { Dividend per share }(t) \text { divided by price per } \\
\text { share }(t-1)\end{array}$ & Compustat \\
\hline$D v c_{t} / N I_{t-1}$ & $D V C$ is common dividends declared & Compustat \\
\hline Totpay/NI & $\begin{array}{l}\text { TOTPAY is total cash dividend plus } \\
\text { purchases of common and preferred stocks }\end{array}$ & Compustat \\
\hline $\log (M V)$ & Log (Market Value) & Compustat \\
\hline Leverage & Debt ratio & Compustat \\
\hline $\mathrm{Cash} / \mathrm{TA}$ & Cash dividend divided by total assets & \\
\hline$R O A$ & Return on Assets & Compustat \\
\hline Sale's Growth & 1year sale's growth rate & Compustat \\
\hline Tobin's $Q$ & $\begin{array}{l}\text { Market value of total assets divided by book } \\
\text { value of total assets }\end{array}$ & Compustat \\
\hline Low Tobin's $Q$ & Takes 1 if Tobin's Q is less than 1 , else 0 & Calculated using Compustat \\
\hline Net FA/TA & Net Plant and equipment/total assets & Compustat \\
\hline Log(Firm age) & Log(firm age+1) & CRSP \\
\hline Past volatility & Past 24 month stock return volatility & CRSP \\
\hline$F C F / T A$ & Free cash flows/total assets & Compustat \\
\hline Positive FCF & Takes 1 if FCF/TA is positive, else 0 & Calculated using Compustat \\
\hline HHI & Herfindahl-Hirschman index & Compustat \\
\hline High HHI & Takes 1 if $\mathrm{HHI}$ is greater than median, else 0 & Calculated using Compustat \\
\hline$E M$ & Absolute magnitude of earnings management & Compustat \\
\hline High EM & Takes 1 if EM is higher than median, else 0 & \\
\hline Better state info & $\begin{array}{l}\text { Takes } 1 \text { if state public information score is } \\
\text { higher than median state number, else } 0\end{array}$ & $\begin{array}{l}\text { Center for Public Integrity } \\
\text { (www.publicintegrity.org) }\end{array}$ \\
\hline \multicolumn{3}{|c|}{ Institutional ownership variables } \\
\hline Total IOR & Total institutional ownership ratio & $13 \mathrm{~F}$ \\
\hline Top10own & Top10 institutional ownership ratio & $13 \mathrm{~F}$ \\
\hline Top10LTIO & $\begin{array}{l}\text { Top } 10 \text { long-term institutional ownership } \\
\text { ratio }\end{array}$ & $13 \mathrm{~F}$ \\
\hline Top10STIO & $\begin{array}{l}\text { Top } 10 \text { short-term institutional ownership } \\
\text { ratio }\end{array}$ & $13 \mathrm{~F}$ \\
\hline Zip2 Top10LTIO & $\begin{array}{l}\text { Annual average Top10 long-term } \\
\text { institutional ownership within the same two } \\
\text { digit ZIP code area }\end{array}$ & $\begin{array}{l}\text { Calculated using } 13 \mathrm{~F} \text { and } \\
\text { Compustat }\end{array}$ \\
\hline FF48 Top10LTIO & $\begin{array}{l}\text { Average Top10 long-term institutional } \\
\text { ownership within the same Fama \& French } \\
48 \text { industry }\end{array}$ & $\begin{array}{l}\text { Calculated using } 13 \mathrm{~F} \text { and } \\
\text { Compustat }\end{array}$ \\
\hline
\end{tabular}

